Annals of Warsaw University of Life Sciences - SGGW

Land Reclamation No 39, 2008: 59-68

(Ann. Warsaw Univ. of Life Sci. - SGGW, Land Reclam. 39, 2008)

\title{
Variability of fluvial transport of the upper Wieprz river
}

\author{
SYLWIA STĘNIEWSKA, KRZYSZTOF STĘPIEWSKI \\ Institute of Earth Sciences, Maria Curie-Skłodowska University in Lublin
}

\begin{abstract}
Variability of fluvial transport of the upper Wieprz river. This paper shows variability of fluvial transport of the Wieprz river. The catchment of the upper Wieprz river to profile at Guciów located in Central Roztocze Region. In Wieprz during the hydrological years 1996-2006 average annual flow is $1.32 \mathrm{~m}^{3} \cdot \mathrm{s}^{-1}$, which correspond to the outflow $-41.5 \mathrm{Mm}^{3} \cdot \mathrm{a}^{-1}$. Extreme values of the flows varied from $0.5 \mathrm{~m}^{3} \cdot \mathrm{s}^{-1}$ to $13,1 \mathrm{~m}^{3} \cdot \mathrm{s}^{-1}$. Outflow the Wieprz river has feature for the snow-rainy hydrological regime. During the study the annual average suspended load amounted $737 \mathrm{Mg}$. The annual average dissolved load amounted $10343 \mathrm{Mg}$. The bed load estimated for less than $10 \%$ of the dissolved load and $1 \%$ of the suspended load. The monthly average suspended load and dissolved load were least in the November and were highest in the April. During the period of researches, the average mechanical denudation rates $2.4 \mathrm{Mg} \cdot \mathrm{km}^{-2} \cdot \mathrm{a}^{-1}$. Chemical denudation rates were much higher $36.1 \mathrm{Mg} \cdot \mathrm{km}^{-2} \cdot \mathrm{a}^{-1}$. Their differentiation are similar in other regions of Poland.
\end{abstract}

Key words: Wieprz river outflow, fluvial transport, denudation.

\section{INTRODUCTION}

In the temperate climate zone, where a river valley density is high, the amount and type of material transported by rivers illustrate rate and direction of relief modelling. Substances transported by a river in form of ions or suspended load and material dragged or rolled on the bed, are the basis to determine catchment denudation balance. An increase of fluvial transport, both of dissolved and suspended load, might be a result of environment contamination and anthropopression growth (Świeca 1998). Rivers in the uplands area between the Vistula and the Bug rivers show considerable variability of fluvial transport, both during one year and from year to year (Maruszczak et al. 1992). The purpose of this paper is to determine seasonal and multi-annual variability of fluvial transport of an upland river, which is characterized by not very intensive anthropopression, against a background of various hydroclimatic conditions.

\section{MATERIALS AND METHODS}

The Roztocze Research Station of Institute of Earth Science, Maria Curie-Skłodowska University in Lublin, carries out an extensive programme of flowing water monitoring in the upper Wieprz and upper Szum river catchments (Rodzik 2005). The Wieprz river outflow and fluvial transport have been measured in the Guciów section since 1996. Since 2005, researches have been led as part of Ordered Grant No. PZB-KBN-086/ /P04/2003. Initial material contributes daily: water level reading, suspended 
load measurement with paper filters using (Brański 1968) and dissolved load measurement applying conductometric method (Markowicz, Pulina 1979). A base of calculation was database including daily data of discharge, suspended-sediment concentration and water mineralization in the years 1996-2006. Because of a few measurements of dragged material and its little content, determined at less than $1 \%$ (Kociuba 2002), in calculations this element of fluvial transport was omitted.

\section{The catchment characteristics}

Roztocze is an elevation located between Wieprz and Bug catchments in NE and San and Dniester catchments in SW. It stretched in form of arch from Kraśnik to Lublin about $14-28 \mathrm{~km}$ wide and $180 \mathrm{~km}$ length. The upper Wieprz catchment locates within the Central (Tomaszów)
Roztocze region, which is built from upper Cretaceous gaizes and opokas, cut by plain surface on $300-330 \mathrm{~m}$ and 320-350 m a.s.l. height (Buraczyński 1997). The upper Wieprz catchment to the Guciów water-gauge (Fig. 1), occupied an area of $300.3 \mathrm{~km}^{2}$.

Among the surface deposits, loesses and sands of various origin predominate, each occupies almost $30 \%$ of the catchment. River valley floors are covered by sands of higher terrace, sandy-silty deposits of floodplain, and patches of peats. The Wieprz river to Krasnobród flows by regulated channel within a vast basin, the $70 \%$ of which is occupied by drained meadows and arable land. Woods cover little more than $20 \%$ of this part of the catchment. An extreme relative height amounts here 90 meters. Downstream of Krasnobród, relative height increases to over 130 meters, and

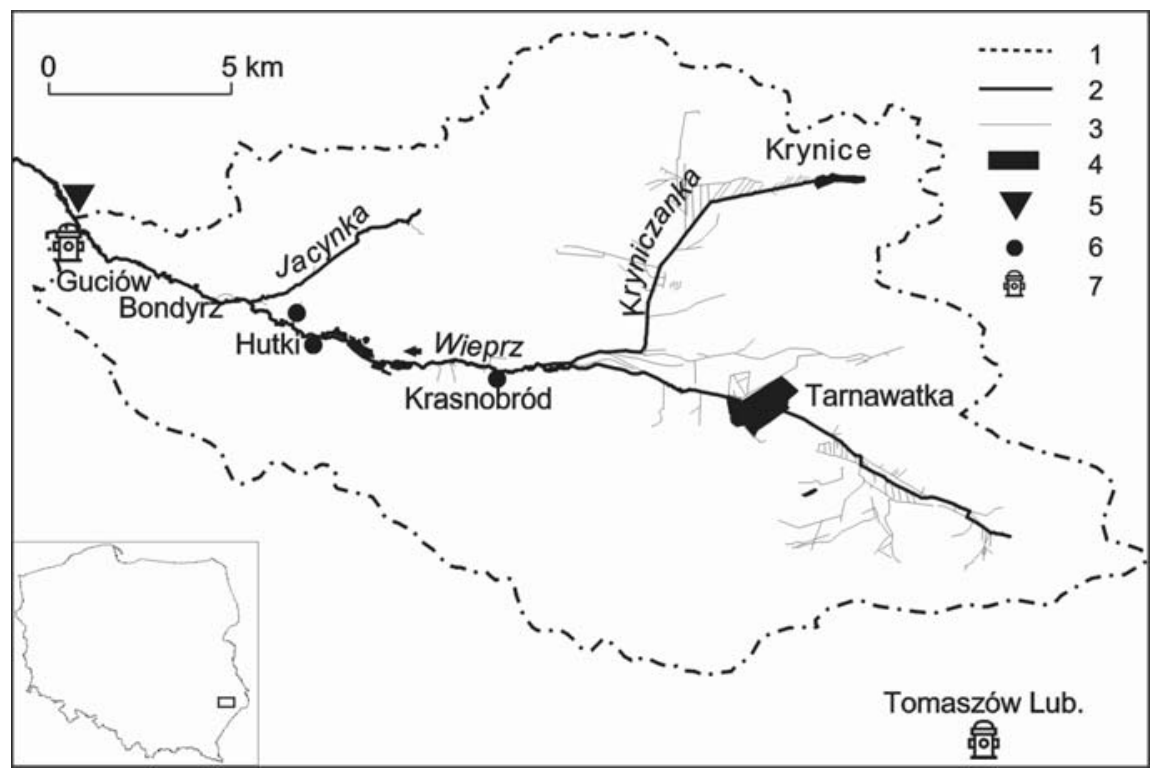

FIGURE 1. The upper Wieprz river catchment to Guciów: 1 - watershed, 2 - rivers, 3 - drainage ditches, 4 - water reservoirs, 5 - water-gauge, 6 - springs, 7 - meteorological stations 
the Wieprz river valley becomes narrow to the width of 1 kilometre. The majority of valley slopes and higher terrace are grown by forests, which occupy over $50 \%$ of this part of the catchment. This section of the Wieprz river, supplied by spring systems (Bartoszewski, Michalczyk 1996), freezes occasionally and is poorly overgrown with water flora. Mainly meandering channel with sandy bed and 5-7 meters width, cuts into depth of $1.2-1.5$ meters in a $200-300 \mathrm{~m}$ wide floodplain occupied by meadows (Stępniewska 2004).

In the upper Wieprz river catchment, the arable land occupies $60.2 \%$, and woods $-33.3 \%$. The brown soil is overgrown by beech woods and dry-ground forests, whereas the rust-coloured and podzolic soils are covered with pine and fir woods (Dębicki et al. 2004). About $1 \%$ of the catchment area is occupied by artificial water reservoirs. The upper Wieprz river catchment is characterized by a small population and urbanization, so the level of environment degradation is low as well (Michalczyk et al. 2004).

Groundwater appears in two connected water-bearing horizons. The main water-bearing horizon occurs in upper Cretaceous rocks in all the catchment area, whereas in valley floors the aquifer in Quaternary deposits is predominant
(Michalczyk 1986). Rich groundwater resources conditioning the occurrence of efficient springs are accompanied by poor river network, which is influenced by permeability of substratum rocks and cover deposits. From its springs to the Guciów, the Wieprz river has only two little right-bank tributaries: Kryniczanka and Jacynka (Fig. 1).

\section{Hydroclimatic conditions}

The Roztocze region is higher than the neighbouring areas so it is characterized by a little lower average air temperature and higher precipitation in comparison to them. According to the data from Tomaszów Lubelski, in the Central Roztocze region the average multi-annual air temperature is $7.0^{\circ} \mathrm{C}$, average temperature of July $-17.4^{\circ} \mathrm{C}$ and average temperature of January $-4.1{ }^{\circ} \mathrm{C}$. Therefore, annual temperature amplitude belongs to the highest ones in Poland (Kaszewski 2004). Annual precipitation in Guciów, calculatedforthehydrologicalyears 1996-2006 , ranged from 607.1 to $873.1 \mathrm{~mm}$. It reached a low level in the first years of this period (1996-1997), it was in general higher with a large number of heavy rains during 1998-2002 period, and it reached again lower levels with growing trend (from low to medium values) in the years 2003-2006 (Tab. 1).

TABLE 1. Annual coefficients of Wieprz river outflow in Guciów and precipitation totals (1996-2006)

\begin{tabular}{|l|c|r|r|r|r|r|r|r|r|r|r|r|}
\hline Coefficient & Measure & 1996 & 1997 & 1998 & 1999 & 2000 & 2001 & 2002 & 2003 & 2004 & 2005 & 2006 \\
\hline $\begin{array}{l}\text { Precipitation } \\
\text { total }\end{array}$ & $\mathrm{mm}$ & 607.1 & 633.2 & 828.1 & 692.3 & 873.1 & 710.3 & 791.8 & 563.2 & 641.2 & 686.7 & 719.0 \\
\hline Discharge & $\mathrm{m}^{3} / \mathrm{s}$ & 0.91 & 0.97 & 1.66 & 1.67 & 1.94 & 1.33 & 1.52 & 1.33 & 1.01 & 1.22 & 0.94 \\
\hline Outflow & $\mathrm{m}^{3} \cdot 10^{6}$ & 28.6 & 30.5 & 52.2 & 52.6 & 61.1 & 42.0 & 47.8 & 41.9 & 32.0 & 38.5 & 29.7 \\
\hline $\begin{array}{l}\text { Specific } \\
\text { outflow }\end{array}$ & $\mathrm{dm}^{3} / \mathrm{s} / \mathrm{km}^{2}$ & 3.0 & 3.2 & 5.5 & 5.6 & 6.3 & 4.4 & 5.1 & 4.4 & 3.4 & 4.1 & 3.1 \\
\hline
\end{tabular}


In Guciów, the average annual precipitation reached $697 \mathrm{~mm}$ and it was lower only by $2 \%$ from average multi-annual precipitation (data from Zwierzyniec), however its variability in time was a little different. In comparison with the values obtained for multi-annual period, in the research time the precipitation in April and July was higher by $30 \%$ and $21 \%$ respectively, whereas it was lower by $15-25 \%$ in September and from November to January. Precipitation in warm season established from 82 to $52 \%$ of annual value. The highest precipitation was reached in July, the lowest one in January (Tab. 2). The average time of snow cover amounted 85 days. The shortest time it lasted in 2001 (52 days), the longest time - in 2006 (119 days).

Against a background of variable precipitation conditions, the Wieprz river discharges in Guciów, especially those of medium and low water, were characterized by relatively low variability in multi-annual period, whereas maximum discharges had an increasing trend (Stępniewska 2007). In the hydrological years 1996-2006 the annual average discharge of Wieprz river in Guciów reached $1.32 \mathrm{~m}^{3} / \mathrm{s}$, which corresponded to the annual average outflow of 41.5 million $\mathrm{m}^{3}$ (Tab. 2). The annual discharge was changing from 0.91 to $1.94 \mathrm{~m}^{3} / \mathrm{s}$, what corresponds to the annual outflow from 28.6 to 61.1 million $\mathrm{m}^{3}$ (Tab. 1). Extreme values of discharge were changing from 0.5 to $13.1 \mathrm{~m}^{3} / \mathrm{s}$.

In Guciów, the Wieprz river outflow is greater in cold season, which is typical of snow-rain regime. The monthly highest average discharges (SSQ) of Wieprz river appear in March and April, whereas the lowest ones in December. The secondary minimum coincides with the beginning of summer. In the years 1996-2006, the monthly average discharges of Wieprz river in the Guciów section were rather similar and ranged from 1.07 to $1.36 \mathrm{~m}^{3} / \mathrm{s}$, except for March and April, when they increased to almost $2 \mathrm{~m}^{3} / \mathrm{s}$. They correspond to outflow amounts from 2.87 to 3.34 million $\mathrm{m}^{3}$, and little over 5 million $\mathrm{m}^{3}$ in March and April (Tab. 1, Fig. 2). Smaller, regulative and local influence on seasonal variability of the Wieprz river outflow is triggered by a pond economy. It causes a discharge decrease in the springtime as a result of reservoirs' filling, and its increase, accompanied by suspension increase and mineralization decrease, by making them empty in autumn. In dry years, reservoirs' filling may periodically cause very low flows (Sadowska 2001).

TABLE 2. Mean monthly precipitation and coefficients of Wieprz river outflow in Guciów (1996-2006)

\begin{tabular}{|l|c|c|c|c|c|c|c|c|c|c|c|c|c|c|c|c|}
\hline Coefficient & Measure & XI & XII & I & II & III & IV & V & VI & VII & VIII & IX & X & XI-IV & V-X & Year \\
\hline $\begin{array}{l}\text { Precipitation } \\
\text { total }\end{array}$ & $\mathrm{mm}$ & 40 & 38 & 35 & 37 & 38 & 62 & 74 & 83 & 121 & 68 & 52 & 48 & 250 & 446 & $\mathbf{6 9 6}$ \\
\hline Discharge & $\mathrm{m}^{3} / \mathrm{s}$ & 1.11 & 1.07 & 1.12 & 1.36 & 1.98 & 1.96 & 1.24 & 1.12 & 1.17 & 1.20 & 1.23 & 1.25 & 1.43 & 1.20 & $\mathbf{1 . 3 2}$ \\
\hline Outflow & $\mathrm{m}^{3} \cdot 10^{6}$ & 2.87 & 2.87 & 2.99 & 3.32 & 5.30 & 5.09 & 3.32 & 2.90 & 3.13 & 3.23 & 3.19 & 3.34 & 22.4 & 19.1 & $\mathbf{4 1 . 5}$ \\
\hline $\begin{array}{l}\text { Specific } \\
\text { outflow }\end{array}$ & $\mathrm{dm}^{3} / \mathrm{s} / \mathrm{km}^{2}$ & 3.7 & 3.6 & 3.7 & 4.5 & 6.6 & 6.5 & 4.1 & 3.7 & 3.9 & 4.0 & 4.1 & 4.1 & 4.8 & 4.0 & $\mathbf{4 . 4}$ \\
\hline
\end{tabular}




\section{Seasonal variability of fluvial transport}

Suspended-sediment concentration in the Wieprz river was changing from 0.1 to $221.8 \mathrm{mg} / \mathrm{dm}^{3}$. The monthly average suspended-sediment concentration ranged from $13.0 \mathrm{mg} / \mathrm{dm}^{3}$ in November to $20.2 \mathrm{mg} / \mathrm{dm}^{3}$ in May (Tab. 3). The monthly average transport of suspended load reached $61.4 \mathrm{t}$ while the average suspended load discharge of $0.04 \mathrm{~kg} / \mathrm{s}$. The smallest amount of suspension (monthly about $40 \mathrm{t}$ ) was transported in November and December, the biggest one in April - $106.5 \mathrm{t}$ (Tab. 3).
The biggest suspension transport was taking place in the springtime (from March to May) and reached $38 \%$ of total amount, which was conditioned by high outflow above all. The smallest amount of suspension was transported in autumn (from September to November) and winter (from December to February), in each season $19 \%$, which was determined by low suspended-sediment concentration above all.

The monthly average values of total mineralization ranged from 223 to $264 \mathrm{mg} / \mathrm{dm}^{3}$ and arranged in inverse proportion to the discharge amount. For

TABLE 3. Mean monthly coefficients of suspended and dissolved load in the Wieprz river in Guciów

\begin{tabular}{|c|c|c|c|c|c|c|c|c|c|c|c|c|c|}
\hline Coefficient & Measure & $\mathrm{XI}$ & XII & I & II & III & IV & $\mathrm{V}$ & VI & VII & VIII & IX & $X$ \\
\hline Suspension & $\mathrm{mg} / \mathrm{dm}^{3}$ & 13.3 & 13.3 & 14.4 & 13.7 & 15.8 & 18.0 & 20.2 & 17.6 & 17.3 & 15.5 & 14.0 & 13.0 \\
\hline \multirow{3}{*}{$\begin{array}{l}\text { Suspended } \\
\text { load }\end{array}$} & $\mathrm{t}$ & 39.6 & 40.1 & 51.3 & 52.4 & 95.9 & 106.5 & 79.2 & 59.2 & 61.9 & 54.5 & 50.8 & 46.0 \\
\hline & $\% *$ & 5.2 & 5.0 & 6.3 & 5.9 & 7.5 & 8.2 & 8.5 & 7.4 & 7.2 & 6.1 & 5.9 & 5.2 \\
\hline & $\mathrm{t} / \mathrm{km}^{2}$ & 0.13 & 0.13 & 0.17 & 0.17 & 0.32 & 0.35 & 0.26 & 0.20 & 0.20 & 0.18 & 0.17 & 0.15 \\
\hline $\begin{array}{l}\text { Total mine- } \\
\text { ralization }\end{array}$ & $\mathrm{mg} / \mathrm{dm}^{3}$ & 250 & 264 & 262 & 255 & 233 & 236 & 255 & 259 & 262 & 262 & 253 & 253 \\
\hline \multirow{3}{*}{$\begin{array}{l}\text { Dissolved } \\
\text { load }\end{array}$} & $\mathrm{t}$ & 719 & 755 & 766 & 830 & 1183 & 1197 & 849 & 741 & 804 & 845 & 806 & 845 \\
\hline & $\%$ & 94.8 & 95.0 & 93.7 & 94.1 & 92.5 & 91.8 & 91.5 & 92.6 & 92.8 & 93.9 & 94.1 & 94.8 \\
\hline & $\mathrm{t} / \mathrm{km}^{2}$ & 2.5 & 2.6 & 2.7 & 3.0 & 4.1 & 4.1 & 2.9 & 2.6 & 2.8 & 2.9 & 2.8 & 3.0 \\
\hline
\end{tabular}

*percentage of total load.

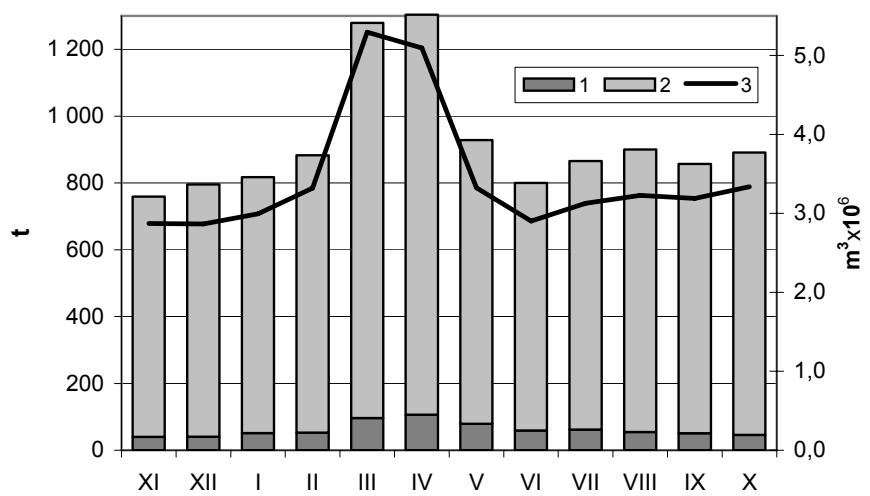

FIGURE 2. The monthly average fluvial transport and the monthly outflow in the hydrological years 1996-2006: 1 - suspended load, 2 - dissolved load, 3 - average outflow 
this reason, transport of dissolved load is less variable during a year in comparison with transport of suspended load, and it refers directly to the outflow amount (Fig. 2). The monthly average transport of dissolved load reached $862 \mathrm{t}$ and the average dissolved load discharge $0.33 \mathrm{~kg} / \mathrm{s}$. The smallest amount of dissolved load is carried out in November - 719 t, the biggest one in March and April - about $1200 \mathrm{t}$ (Tab. 3). It has an influence on domination of spring transport $(31 \%)$, while transport is balanced during the other seasons (each 23\%). In the light of measurements taking in Guciów, there was found that even more than a half of total material amount (suspended and dissolved), transported by the Wieprz river, may be carried out during high water stages (Kociuba, Stępniewska 2002).

\section{The multi-annual variability of fluvial transport}

The annual average coefficients of suspended-sediment concentration ranged from 7.0 to $30.6 \mathrm{mg} / \mathrm{dm}^{3}$. The annual average transport of suspended load reached $737 \mathrm{t}$ and it was changing in individual years from 243 to $1607 \mathrm{t}$.
The dissolved load concentration (total mineralization) was changing from 26 to $372 \mathrm{mg} / \mathrm{dm}^{3}$ in analysed period. However, the average coefficients of mineralization were not much diversified - from 244 to $266 \mathrm{mg} / \mathrm{dm}^{3}$. The dissolved load transport reached on average 10.3 thousand tons within a year and it was changing from 7.4 to 15.9 thousand $t$ (Tab. 4).

The first (dry) two years were characterized by the relatively low annual average discharge of the Wieprz river and low rise of water in the spring. In this time, the river carried out from 38 to $51 \mathrm{t}$ in form of suspension and from 7.4 to 7.5 thousand $t$ of dissolved load (Tab. 4, Fig. 3). The wet years 1998-2000 brought significant increase of spring efficiency, and the annual average discharge and extreme discharges increased by $75-100 \%$ as a result of increased surface and underground water supply (Stępniewska, Stępniewski 2004). The outflow increase caused over threefold growth of suspended load transport and almost twofold growth of dissolved load transport (Fig. 3). The biggest suspended load transport, similarly to suspended-sediment concentration, was recorded

TABLE 4. Annual coefficients of suspended and dissolved load in the Wieprz river in Guciów

\begin{tabular}{|l|c|r|r|r|r|r|r|r|r|r|r|r|}
\hline Coefficient & Measure & 1996 & 1997 & 1998 & 1999 & 2000 & 2001 & 2002 & 2003 & 2004 & 2005 & 2006 \\
\hline Suspension & $\mathrm{mg} / \mathrm{dm}^{3}$ & 13.6 & 14.3 & 30.6 & 22.8 & 19.3 & 15.9 & 14.1 & 13.9 & 7.0 & 10.8 & 8.3 \\
\hline \multirow{2}{*}{$\begin{array}{l}\text { Suspended } \\
\text { load }\end{array}$} & $\mathrm{t}$ & 379 & 514 & 1607 & 1281 & 1194 & 751 & 699 & 694 & 243 & 479 & 271 \\
\cline { 2 - 13 } & $\%$ & 4.8 & 6.5 & 10.9 & 8.9 & 7.0 & 6.5 & 5.7 & 6.7 & 2.9 & 4.9 & 3.5 \\
\cline { 2 - 13 } & $\mathrm{t} / \mathrm{km}^{2}$ & 1.3 & 1.7 & 5.4 & 4.3 & 3.9 & 2.4 & 2.3 & 2.3 & 0.8 & 1.6 & 0.9 \\
\hline $\begin{array}{l}\text { Total mine- } \\
\text { ralization }\end{array}$ & $\mathrm{mg} / \mathrm{dm}^{3}$ & 260 & 244 & 253 & 256 & 266 & 264 & 246 & 246 & 255 & 247 & 255 \\
\hline \multirow{2}{*}{$\begin{array}{l}\text { Dissolved } \\
\text { load }\end{array}$} & $\mathrm{t}$ & 7455 & 7419 & 13144 & 13085 & 15932 & 10747 & 11467 & 9602 & 8125 & 9288 & 7513 \\
\cline { 2 - 13 } & $\%$ & 95.2 & 93.5 & 89.1 & 91.1 & 93.0 & 93.5 & 94.3 & 93.3 & 97.1 & 95.1 & 96.5 \\
\cline { 2 - 12 } & $\mathrm{t} / \mathrm{km}^{2}$ & 24.8 & 24.7 & 43.8 & 43.6 & 51.9 & 35.0 & 60.2 & 31.3 & 26.5 & 30.9 & 25.0 \\
\hline
\end{tabular}

*percentage of total load. 


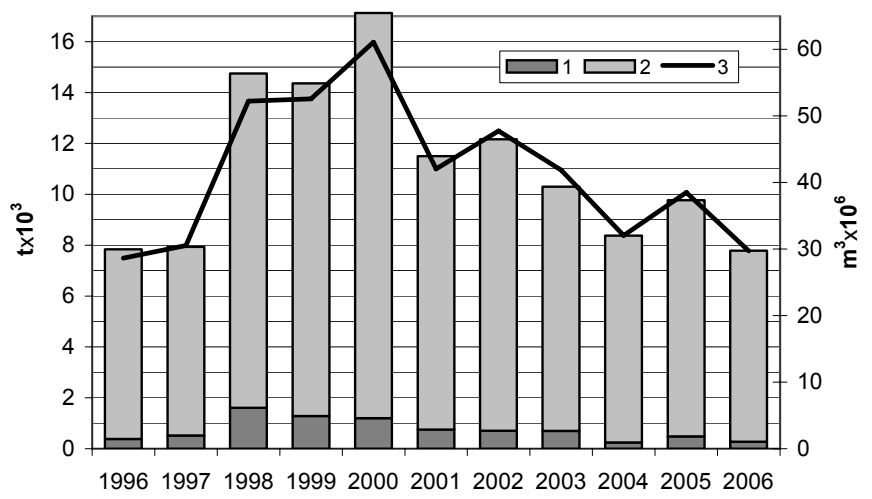

FIGURE 3. The fluvial transport and the annual outflow in the hydrological years 1996-2006: 1 - suspended load, 2 - dissolved load, 3 - average outflow

in 1998 that is on the beginning of the wet period after a series of dry years. The biggest dissolved load transport was recorded in 2000, which was characterized by the highest precipitation and total outflow (Tab. 1, Fig. 3) and the little changes of total mineralization.

In the next years, there was recorded a decreasing trend of the annual average discharge, which has been reducing since 2001. In this period, which was characterized by average precipitation and outflow conditions (Michalczyk et al. 2004), transport coefficients were considerable lower (Fig. 3). It concerned mainly suspension, the transport of which had gradual diminishing tendency, to $240 \mathrm{t}$ in 2004, simultaneously with fast decrease of suspended-sediment concentration and suspended load. Less decrease was noted in dissolved load transport, which fell to 7.5 thousand $t$ in 2006 (Tab. 4).

\section{DISCUSSION}

Fluvial transport of the upper Wieprz river was quite balanced during all year with a minor predominance in cold half year in which about $53 \%$ of annual suspended and dissolved load was carrying out, and it was referring to outflow course (Fig. 2). It is a result of small outflow variability, typical of rivers in the Roztocze region (Stępniewska, Stępniewski 2004; Świeca et al. 2004; Stępniewska 2007), and connected with the predominance of groundwater supply. Dissolved substances constituted from 89 to $97 \%$ of total load in individual years (Fig. 3). The proportion of suspended load was lower by one order of magnitude (from 3 to $11 \%$ ), and the participation of dragged load $(<1 \%)$ was very small (Kociuba 2002).

In total transport, a large proportion of suspended load was observed in transition period from dry to wet years, and then it decreased even when outflow still increased. It indicates on rapid triggering of mineral material at positive change of outflow trend and quite rapid exhaustion of its "reserves", presumably connected with adaptation of channel to higher discharges. Seasons of low discharges are characterized by accumulation of material in the riverbed. 
The annual average coefficients for the upper Wieprz river, approximately amount: chemical denudation $-36.1 \mathrm{t} / \mathrm{km}^{2}$ and mechanical one $-2.4 \mathrm{t} / \mathrm{km}^{2}$ and were estimated on the basis of carried substances amount. They are considerably lower in comparison with similar other upland catchments on account of size and usage (Ciupa 1991; Maruszczak et al. 1992). In two catchments, sited in adjacent Lublin Upland, these coefficients in 1978-1982 period approximately amounted: in the Bystra catchment $78.6 \mathrm{t} / \mathrm{km}^{2}$ and $16.4 \mathrm{t} / \mathrm{km}^{2}$ and in the Uherka catchment 74.7 and $7.7 \mathrm{t} / \mathrm{km}^{2}$. In case of chemical denudation, they were double higher than in the upper Wieprz catchment. In turn, coefficients of mechanical denudation were three to sixfold higher. Amounts of the coefficients and also relations between them are similar to that ones in the north Poland lowlands (Kostrzewski et al. 1994; Smolska 1996).

Maruszczak et al. (1992) assume that coefficient of mechanical denudation illustrates real rate of this process in the catchment area only in 10-20\%. Next, during analyses of chemical denudation rate with use of coefficient, estimated on the basis of dissolved load outflow, anthropogenic water pollution should be taken into consideration. As Świeca (1998) provides, pollution in the Roztocze part of the Wieprz river, mainly from agricultural origin, makes only $9.8 \%$ of total dissolved load outflow.

\section{CONCLUSIONS}

Coefficients of fluvial transport in the upper Wieprz river catchment in the Central Roztocze region - in spite of diversified relief and high specific outflow - are low and little variable in comparison with other, similar upland catchments. The main reason is a big percentage of natural landscape elements, as forests and meadows. Low coefficients of specific denudation, typical of lowlands, and their mutual relation, are also influenced by material retention on vast, flat valley floors.

Variability and at the same time the amount of fluvial transport in the upper Wieprz river catchment mainly depends on the outflow changeability. The suspended load transport is dependent on sedimentation conditions in a channel as well, hence its changes are bigger and they concern mainly variability every year, which is directly dependent on the outflow amount and indirectly on the weather conditions.

\section{REFERENCES}

BARTOSZEWSKI S., MICHALCZYK Z. 1996: Dorzecze górnego Wieprza. [w:] Z. Michalczyk [red.], Źródła Roztocza. Wyd. UMCS. Lublin; 87-99.

BRAŃSKI J. 1968: Oznaczanie ilości unosin metodą wagową bezpośrednią przy użyciu sączków. Prace PIHM; 13-21.

BURACZYŃSKI J. 1997: Roztocze. Budowa, rzeźba, krajobraz. Wyd. UMCS. Lublin; 1-190.

CIUPA T. 1991: Wspótczesny transport fluwialny w zlewni Biatej Nidy. WSP. Kielce; 1-150.

DĘBICKI R., CHODOROWSKI J., GAWRYSIAK L. 2004: Charakterystyka pokrywy glebowej. [w:] A. Świeca [red.], Przyrodnicze uwarunkowania dynamiki obiegu wody i natężenia transportu fluwialnego $w$ zlewni górnego Wieprza. Wyd. UMCS. Lublin; 33-40.

KASZEWSKI B.M. 2004: Warunki klimatyczne. [w:] A. Świeca [red.], Przyrodnicze uwarunkowania dynamiki obiegu wody i natężenia transportu fluwialnego $w$ zlewni górnego Wieprza. Wyd. UMCS. Lublin; 41-49.

KOCIUBA W. 2002: Współczesny rozwój dna doliny Wieprza. Rozprawa doktorska, INoZ UMCS, Lublin; 1-243.

KOCIUBA W., STĘNIEWSKA S. 2002: Rola wezbrań $\mathrm{w}$ transporcie rumowiska rzecznego 
górnego Wieprza. Przeglad Nauk., Inżynieria i Ksztaltowanie Środowiska. 9. 2(25); 102-111.

KOSTRZEWSKI A., MAZUREK M., ZWOLIŃSKI Z. 1994: Dynamika transportu fluwialnego jako odbicie funkcjonowania systemu zlewni. Stow. Geomorfologów Polskich, Poznań; $1-165$.

MARKOWICZ M., PULINA M. 1979: Ilościowa pótmikroanaliza chemiczna wód $w$ obszarach krasu węlanowego. Uniwersytet Śląski. Katowice; 1-67.

MARUSZCZAK H., RODZIK J., ŚWIECA A. 1992: Denudacja mechaniczna i chemiczna we wschodniej części pasa wyżyn południowopolskich. [w:] A. Kotarba [red.], System denudacyjny Polski. Pr. Geogr. Nr 155, Wyd. PAN. Wrocław; 105-131.

MICHALCZYK Z. 1986: Warunki występowania i krązenia wód na obszarze Wyżyny Lubelskiej i Roztocza. Wyd. UMCS. Lublin; 1-199.

MICHALCZYK Z. 1997: Przepływy Wieprza w profilu wodowskazowym Guciów w latach 1995-1996. [w:] Kompleksowe badania środowiska przyrodniczego Roztocza. Wyd. UMCS. Lublin; 73-77.

MICHALCZYK Z. 2004: Charakterystyka stosunków wodnych. [w:] A. Świeca [red.], Przyrodnicze uwarunkowania dynamiki obiegu wody $i$ natężenia transportu fluwialnego $w$ zlewni górnego Wieprza. Wyd. UMCS. Lublin; 50-64.

MICHALCZYK Z., KASZEWSKI B. M., GRĄDZIEL T. 2004: Zróżnicowanie warunków retencji i spływu powierzchniowego. [w:] A. Świeca [red.], Przyrodnicze uwarunkowania dynamiki obiegu wody i natężenia transportu fluwialnego w zlewni górnego Wieprza. Wyd. UMCS. Lublin; 87-93.

RODZIK J. 2005: Funkcje i zadania Roztoczańskiej Stacji Naukowej UMCS w Guciowie oraz ich realizacja. Roztoczańskie Spotkania, 4, 189-197.

RODZIK J., FURTAK T., MACIEJEWSKA E., STĘPNIEWSKA S., STĘPNIEWSKI K. 2007: Zróżnicowanie transportu fluwialnego na obszarze Roztoczańskiego Parku Narodowego w latach 1998-2003. [Variability of fluvial transport in the Roztocze National Park in 1998-2003] [w:] Z. Michalczyk [red.], Obieg wody $w$ środowisku naturalnym $i$ przeksztatconym. Wyd. UMCS. Lublin; 445-451 [Engl. Abst.].

SADOWSKA S. 2001: Wpływ gospodarki stawowej na kształtowanie odpływu rzecznego gór- nego Wieprza w „mokrych” latach 1998-2000. [w:] Materiaty Ogólnopolskiej Konferencji Hydrologicznej, Kielce - Wólka Milanowska, 25-27 IX $2001 r$. Wyd. IG AŚ. Kielce; 97-99.

SMOLSKA E. 1996: Funkcjonowanie systemu korytowego $w$ obszarze mtodoglacjalnym na przykładzie górnej Szeszupy (Pojezierze Suwalskie). Wydz. Geogr. i Stud. Reg. UW, Warszawa; 1-121.

STEPNIEWSKA S., STĘPNIEWSKI K. 2004: Zmienność przepływów w rzekach Roztoczańskiego Parku Narodowego w latach 1998-2003. [w:] Z. Michalczyk [red.], Badania geograficzne $w$ poznawaniu środowiska. Wyd. UMCS. Lublin; 347-353.

STĘPNIEWSKA S. 2007: Zmienność odpływu górnego Wieprza. [Runoff variability of the upper Wieprz river] [w:] Z. Michalczyk [red.], Obieg wody $w$ środowisku naturalnym $i$ przeksztatconym. Wyd. UMCS. Lublin; 511-520 [Engl. Abst.].

ŚWIECA A. 1998: Wpływ czynników antropogenicznych na rzeczny odplyw roztworów i zawiesin na międzyrzeczu Wisty i Bugu. Wyd. UMCS. Lublin; 1-326.

Streszczenie: Zmienność transportu fluwialnego górnego Wieprza. Przedstawiono wielkość odpływu roztworów i zawiesin ze zlewni górnego Wieprza na Roztoczu Środkowym, obliczoną na podstawie codziennych pomiarów ładunku zawiesin i roztworów w profilu Guciów, w latach 1996-2006. Rytm odpływu Wieprza ma tu cechy ustroju śnieżno-deszczowego. Średni roczny przepływ wyniósł $1,32 \mathrm{~m}^{3} / \mathrm{s}$, natomiast skrajne wielkości przepływu zmieniały się od $0,5 \mathrm{~m}^{3} / \mathrm{s}$ do $13,1 \mathrm{~m}^{3} / \mathrm{s}$. Średni roczny odpływ zawiesin wyniósł 737 t i zmieniał się w od 243 do $1607 \mathrm{t}$. Odpływ roztworów wyniósł średnio 10,3 tys. $t$ w ciagu roku i zmieniał się od 7,4 do 15,9 tys. t. W ciagu roku wielkość transportu rumowiska wleczonego po dnie oceniono na nie więcej niż $10 \%$ transportu zawiesin i $1 \%$ transportu całkowitego. Średni miesięczny odpływ zawiesin wyniósł $61,4 \mathrm{t}$ i zmieniał się od ok. $40 \mathrm{t}$ w listopadzie i grudniu do 106,5 t w kwietniu. Średni miesięczny odpływ roztworów wyniósł $862 \mathrm{t}$ i zmieniał się od $719 \mathrm{t}$ w listopadzie do blisko $1200 \mathrm{t}$ w marcu i kwietniu. Sezonowo wielkość transportu fluwialnego jest wyrównana, $\mathrm{z}$ niewielką przewagą w półroczu chłodnym i nawiązuje do przebiegu średnich miesięcznych przepływów. 
MS. received April 2008

Authors' addresses:

Sylwia Stępniewska

Instytut Nauk o Ziemi UMCS w Lublinie

Kraśnicka 2 C,D, 20-718 Lublin

Poland

e-mail: sylwias1@onet.eu

\section{Krzysztof Stępniewski}

Roztoczańska Stacja Naukowa

Instytut Nauk o Ziemi UMCS w Lublinie

Guciów 20

Poland 